\title{
Respon Dunia Internasional Terhadap Tragedi Kemanusiaan Rohingya
}

\author{
Gonda Yumitro* \\ yumitro@gmail.com
}

\begin{abstract}
Abstrak
Kasus Rohingya sebagai tragedi kamanusiaan sudah berlangsung selama beberapa tahun. Dengan peningkatan intensitas publikasi dan jumlah pengungsi lintas Negara, pengaruh konflik Rohingya tidak hanya pada level domistik, melainkan sudah memberikan pengaruh dan menjadi isu regional bahkan Internasional. Oleh karena itu, makalah ini akan menganalis bagaimana dunia Internasional merespon tragedi kemanusiaan Rohingya. Melalui konsep Responsibility to Protect, makalah deskriptif dengan metode studi pustaka ini menggambarkan bahwa respon Internasional terhadap isu Rohingya cukup massif baik pada level bilateral, regional, maupun Internasional. Namun demikian, berbagai upaya yang dilakukan belum bersifat sistematis untuk menyelesaikan akar persoalan. Beberapa respon yang muncul lebih terlihat sebagai upaya politik untuk pencitraan diri daripada langkah ril menyelesaikan masalah, misalnya dengan mendeportasi para pengungsi Rohingya yang sudah kehilangan kewarganegaraan mereka.
\end{abstract}

Kata Kunci: Respon, ASEAN, Internasional, Kemanusiaan, Robingya

\begin{abstract}
Rohingya case has emerged as humanism tragedy since last several years. Due to the increase of publication intensity and the number of refugees crosses countries, the influences of Rohingya case not only affected the domestic issues but also have influenced and emerged as a regional and International issue. Therefore, this paper aims to analyze the International response on the human right tragedy on Rohingya issue. Through the Responsibility to Protect concept, this descriptive paper using literature reviews method describes the massif response of the International world in the level of bilateral, regional, and International. However, the response founded have not been systematic in nature solving the root of problems of the Rohingya issue. Some of the responses mostly concern on the self-political interests than the real efforts to solve the issue. Even some countries deport Rohingya refugees whose being lost their citizenship.
\end{abstract}

Keywords: Respons, ASEAN, International, Humanitarian, Robingya

\section{Pendahuluan}

Sejak tahun 2015, berbagai media Indonesia dan Internasional diramaikan oleh pemberitaan tentang pengungsi Rohingya dengan kondisi memprihatinkan. Di Indonesia misalnya, mereka dibantu oleh masyarakat Aceh, yang akhirnya mendorong pemerintah dan masyarakat Indonesia untuk juga memberikan pertolongan. Berbagai

${ }^{*}$ Korespondensi: Prodi. Hubungan Internasional. Fakultas Ilmu Sosial dan Ilmu Politik. GKB I Lt.6. Universitas Muhammadiyah Malang, Jl. Raya Tlogomas no. 246 Malang, telp. 0341-464318, Email: yumitro@gmail.com 
kegiatan solidaritas pun dilakukan untuk membantu mereka. Seminar dan penggalangan dana menjadi wujud solidaritas terhadap penderitaan masyarakat Rohingya diadakan. Meskipun relatif "terlambat" mengingat isu ini sebenarnya sudah berlangsung sangat lama, tetapi upaya pertolongan terhadap para pengungsi Rohingya ini perlu mendapatkan apresiasi yang baik. Bahkan, konflik Rohingya telah menyebabkan sekitar 43 persen penduduknya menjadi pengungsi, dan lebih dari 87 persen dari mereka kekurangan kebutuhan dasar seperti sandang, pangan, papan, pelayanan kesehatan dan akses pendidikan bagi anak-anak mereka. Yang jelas, konflik ini telah menjadi tragedi kemanusian, perdamaian dan keamanan dunia yang punya implikasi terhadap kawasan ASEAN (Rahman, 2015: 288-295).

Bahkan beberapa Negara tetangga juga mendapatkan dampak langsung dan tidak langsung dari peristiwa ini. Hal ini terutama berkaitan dengan isu keamanan yang berkaitan dengan para pengungsi Rohingya yang memasuki beberapa Negara tetangga dalam upaya mencari keamanan dari tekanan rezim pemerintahan Myanmar. Akibatnya isu ini pun berkembang menjadi isu kawasan, dimana ASEAN sebagai lembaga yang cukup perhatian dengan isu kemanusiaan tidak bisa berlepas tangan (Kaewjullakarn and Kovudhikulrungsri, 2015). Apalagi sejauh ini meskipun masih mempunyai kekuatan yang terbatas, ASEAN sudah mempunyai lembaga yang bernama the ASEAN Intergovernmental Commission on Human Rights (AICHR).

Oleh karena itu, tulisan ini akan mengurai bagaimana respon dunia Internasional terhadap Tragedi kemanusiaan yang terjadi di Rohingya selama ini baik pada level bilateral, regional, maupun Internasional?. Hal ini penting untuk melihat perhatian dunia Internasional terhadap isu kemanusiaan dan keberpihakan mereka terhadap moralitas. Sejauh ini, bicara tentang politik Internasional lebih banyak diwarnai oleh isu kepentingan dan upaya untuk menghargai kedaulatan bangsa suatu Negara. Dalam kasus yang kompleks ini, maka apakah nuansa politik tersebut masih terlihat dalam isu kemanusiaan atau tidak akan bisa terlihat. Sebelum itu, terlebih dahulu akan diuraikan gambaran persoalan yang terjadi di Rohingya. 


\section{Metodologi}

Untuk menjawab pertanyaan dalam rumusan masalah pada penelitian ini maka digunakan metode deskriptif kualitatif. Adapun metode pengumpulan data sebagai bahan analisa dilakukan dengan cara studi pustaka. Beberapa sumber yang digunakan berasal dari buku, jurnal, dan beberapa dokumen penting lainnya yang terkait dengan isu pengungsi rohingya.

\section{Konseptual}

Mengingat isu yang terjadi pada para pengungsi merupakan isu kemanusiaan dan respon yang diambil oleh dunia Internasional sebagai bentuk perhatian mereka terhadap nilai moral kemanusiaan, maka konsep yang digunakan untuk menganalisa isu ini adalah konsep Responsibility to Protect.

Konsep Responsibility to Protect dikenalkan pada tahun 2001 saat terjadi perang Kosovo sebagai media bagi PBB untuk melakukan intervensi kemanusiaan (Chandler, 2010:161-166). Dengan cara ini maka upaya untuk melakukan penanganan terhadap kasus kemanusiaan bisa dilakukan secara legal. Pada aspek lain, hal ini tidak termasuk dalam kategori intervensi militer yang seringkali justru menambah kisruh persoalan konflik yang sedang berkembang.

Ide Responsibility to Protect merupakan produk dari dilema yang dihadapi dalam konsep politik modern antara isu kemanusiaan dan kedaulatan suatu bangsa. Pada satu aspek kemanusiaan harus dijunjung tinggi karena menyangkut harkat dan martabat kehidupan manusia. Namun pada aspek yang lain, konsep nation state di tengah masyarakat modern meletakkan kedaulatan suatu bangsa sebagai kedudukan paling tinggi dalam politik tanpa adanya hak intervensi dari Negara lain.

Pada dua posisi yang ekstrim ini, maka Responsibility to Protect meletakkan moralitas atas nama kemanusiaan sebagai kewajiban yang harus didahulukan. Sekjen PBB Koffi Annan dalam sidang umum PBB menyatakan bahwa masyarakat Internasional perlu menyepakati upaya untuk merespon kekerasan yang terjadi secara sistematik terhadap kemanusiaan dan hukum Internasional. Oleh karena itu, konsep Responsibility to 
Proctect merupakan solusi yang memiliki analisis sistematik dan kekuatan hukum dengan dukungan Negara-negara dan masyarakat Internasional yang legal untuk menangani kekerasan yang berkelanjutan. Meskipun demikian, dalam realitanya tetap saja ada unsur politik yang tersembunyi dalam Responsibility to Protect. Terkadang mereka menggunakan isu kemanusiaan untuk meraih kepentingan tertentu. Negara besar biasanya menggunakan konsep ini untuk menjustifikasi intervensi mereka terhadap Negara lain (Zongze, 2012). Adapun Negara yang tidak cukup kuat sering menggunakan Responsibility to Protect sebagai alat untuk membangun citra rejim sehingga mereka mendapatkan dukungan dan legitimasi dari pemerintah sebagai rejim yang berpihak kepada isu kemanusiaan. Hal inilah yang akhirnya menjadi kendala upaya Responsibility to Protect tidak berjalan sebagaimana seharusnya.

\section{Persoalan Muslim Rohingya}

Myanmar merupakan salah satu Negara ASEAN yang merdeka dari jajahan Inggris pada tanggal 4 Januari 1948 dan dalam waktu yang lama dipimpin oleh pemerintahan yang militeristik (Arendshorst, 2009:102). Pada masa kekuasaan militer, selain otoritarianisme politik militer juga diwarnai oleh berbagai korupsi dan keterlibatan militer dalam penjualan obat-obatan terlarang (Sarkin \& Pietschmann, 2003:371). Hal ini menggambarkan bahwa proses demokratisasi di Myanmar belum cukup matang dan baru pada dekade terakhir.

Pada awal tahun 2003 misalnya, beberapa kelompok pro demokrasi seperti halnya Aung San Suu Kyi, dan beberapa pengikutnya justru mendapatkan perlakukan tidak manusiawi dan dipenjara karena penentangan mereka terhadap rezim militer. Akhirnya karena tuntutan dari berbagai elemen dunia Internasional mereka pun dilepaskan dan rejim militer di Myanmar mulai digantikan dengan rezim demokratis. Kebebasan Aung San Suu Kyi pada tahun 2010 meskipun belum sepenuhnya mendapatkan dukungan dari kelompok militer merupakan pertanda bagi demokratisasi bagi Negara ini (Steinberg, 2010:35-59). 
Dalam hal penduduk, Myanmar merupakan negara multietnik, yang 70\% penduduknya merupakan suku Burma, Bamar, Shan, Kachin, Kayin (Karen), Kayah (Karenni), Chin dan Mon. Dari berbagai etnik tersebut, ada kelompok muslim Rohingya yang merupakan kelompok minoritas yang tinggal di daerah Arakan, yang berbatasan dengan Bangladesh. Dari segi agama, meskipun 75\% penduduk beragama Budha, tetapi terdapat juga masyarakat yang beragama Kristen, Islam (20\%), Hindu dan animisme di Rohingya. Bahkan sebagian data mengindikasikan bahwa lebih dari 40,7 \% penduduk Rakhine adalah masayrakat Muslim (Letchamanana, 2013:86). Namun dalam realitanya, hubungan antara umat beragama tersebut tidak berlangsung baik.

Sebagai kelompok mayoritas, umat Budha seringkali bertindak sewenangwenang terhadap umat muslim sebab menurut mereka Burma hanya untuk Budha dan orang Islam dianggap orang asing. Akhirnya berbagai Tragedi terhadap kelompok muslim mereka lakukan. Bahkan, sikap umat Budha ini didukung oleh negara. Karenanya Myanmar dikenal sebagai negara yang mempunyai raport buruk dalam urusan HAM. Apalagi negara terkorup kedua di dunia setelah Somalia dan miskin ini dikuasi oleh Junta militer.

Apa yang dilakukan oleh kelompok Budha ini merupakan upaya untuk menutup mata dari sejarah muslim di Myanmar. Masyarakat Rohingya yang sebenarnya sudah tinggal selama beberapa abad di Myanmar mendapatkan perlakuan yang tidak manusiawi dari kelompok Budha. Tidak sedikit dari mereka yang dibunuh, disakiti, diusir, dan tidak mendapatkan perlakuan layajnya manusia. Padahal sebenarnya mereka masih merupakan penduduk Myanmar, hanya saja dalam perkembangannya kewarganegaraan mereka pun dipersoalan.

Dalam sikap resmi berdasarkan Undang-Undang Kewarganegaran Myanmar tahun 1982, pemerintah bahkan tidak mengakui Rohingya sebagai bagian dari Ras di Myanmar. Hal ini terlihat dari statemen Kementerian Luar Negeri Myanmar bahwa terdapat 135 ras yang tinggal di Myanmar sekarang. Adapun Rohingya tidak termasuk salah satu dari ras tersebut. Menurut mereka, ras Rohingya merupakan kelompok yang memasuki Myanmar secara ilegal. Bahkan lebih para lagi, keberadaan mereka tidak diakui 
sebagai warga Negara, demikian juga sebagai warga asing (Lewa, 2009:11). Intinya masyarakat Rohingya harus meninggalkan Myanmar.

Dengan sikap ini, meskipun jumlah muslim Myanmar cukup besar, berkisar 10 juta orang, tetapi berdasarkan aturan hukum Myanmar, maka posisi mereka pun tetap termarginalkan. Mereka tidak mendapatkan hak-hak sebagai warga negara. Bahkan ada indikasi untuk menghabiskan ras Rohingya di negeri ini. Mereka pun tidak bisa melakukan banyak hal di negeri yang sudah ditempati selama ribuan tahun. Pasalnya, pemerintah juga melarang mereka untuk melakukan perpindahan tempat secara leluasa. Konsekuensinya adalah mereka juga tidak bisa mengakses berbagai fasilitas kesehatan, pendidikan, dan kebutuhan pokok lainnya. Bahkan untuk keperluan menikah pun mereka harus mengeluarkan sejumlah uang yang tidak sedikit (Ekeh \& Smith, 2007).

Posisi umat Budha tersebut diperkuat oleh aturan hukum Myanmar yang hanya mengenal tiga jenis warga negara. Mereka adalah warga yang nenek moyangnya sudah di Myanmar sebelum tahun 1823. Dengan kategori tahun 1823 ini maka masyarakat Myanmar bisa membedakan masyarakat antara kami dan mereka. Ada juga masyarakat kelas lainnya yang datang saat atau sebelum perang Anglo Burma. Serta penduduk yang lahir di luar negeri dari keturunan Myanmar. Sementara Rohingya tidak dikategorikan sebagai salah satu dari warga negara tersebut (Nemoto, 2013).

Aturan ini muncul sebagai gambaran sentimen xenophobia pemerintah Myanmar terhadap warga muslim yang sudah berabad abad lamanya menjadi penduduk asli Arakan. Sikap ini pun didukung oleh militer yang bersikap keras terhadap masyarakat Rohingya. Hal ini terlihat dari upaya eksodus masyarakat Rohingya dari Myanmar ke berbagai negara lain yang pada akhirnya juga memunculkan berbagai persoalan baru yang belum bisa diselesaikan sepenuhnya sampai sekarang.

Munculnya sikap sewenang-wenang dari pemerintah Myanmar terhadap masyarakat Rohingya karena mereka menganggap masyarakat yang tinggal di daerah Arakan ini dinilai bukan sebagai orang asli Myanmar. Mereka diindikasikan lebih dekat dengan bangsa India dan Bangladesh. Sebagian sumber menyatakan bahwa mereka sudah menempati wilayah tersebut sejak ribuan tahun yang lalu. Namun pada tahun 1700 
mereka dikuasai oleh Bangsa Myanmar yang kemudian menjadikan mereka sebagai kelompok minoritas karena beberapa perbedaan, termasuk agama (Rahman, 2015: 288295).

Pada masa penjajahan Inggris penduduk Rohingya belum mengalami persoalan seperti yang mereka rasakan sekarang. Bahkan beberapa reference menunjukkan bahwa bangsa dengan jumlah penduduk sekitar 1,4 juta ini mempunyai hubungan erat dan berdekatan dengan masyarakat Budha (Holland, 2002). Satu dengan lainnya saling membantu dan hidup seperti halnya masyarakat majemuk yang memahami makna toleransi. Apalagi mereka sudah hidup bersama dalam waktu yang lama.

Namun ketika Myanmar merdeka dan menjadi Negara pada tahun 1948, pemerintah Myanmar mulai mengidentifikasi masyarakat Rohingya bukan sebagai penduduk asli. Bahkan pada tahun 1982, pemerintah mengeluarkan aturan yang menganggap Rohingya bukan sebagai penduduk Myanmar melalui Citizenship Act dan tidak bisa mendapatkan akses terhadap kesehatan, pendidikan, pekerjaan, dan kebebasan dalam menjalankan keyakinan beragama mereka (Baskoro, 2016).

Hal ini dikarenakan masyarakat Rohingya tidak mempunyai dokumen yang bisa membuktikan bahwa mereka merupakan penduduk Myanmar. Sejauh ini ketika mereka ingin mengurus surat menyurat sebagai warga Negara, pemerintah sudah menolak untuk memberikan pelayanan kepada mereka. Oleh karena itu, keberadaan masyarakat Rohingya juga bisa disebut sebagai bangsa tanpa Negara. Mereka punya identitas, tetapi mereka mereka tidak punya power dan struktur pemerintahan yang mampu memberikan pelayanan sebagai warga Negara kepada mereka. Bahkan mereka berada dalam kondiri tertekan dan mendapatkan beragam perlakuan diskriminatif dari pemerintah Myanmar. Bisa dikatakan mereka tidak lagi mendapatkan kesempatan untuk mengakses hak mereka yang paling mendasar sekali pun, bahkan untuk hidup karena keberadaanya yang menjadi target pembunuhan oleh pemerintah (Gill, 2015).

Tidak hanya itu, masyarakat Rohingya pun menjadi korban penangkapan, pemerkosaan, pembunuhan massa, kerja paksa, dan berbagai Tragedi lainnya. Bahkan pernah dalam satu waktu, 5000 pemuda muslim Rohingya dibunuh secara missal, dan 
waktu yang lain 100.000 dibantai secara masal. Berbagai tempat usaha muslim Rohingya juga direbut, tidak sedikit yang dirusak. Rumah mereka dibakar. Demikian juga dengan masjid yang seringkali menjadi sasaran penghancuran oleh kelompok Budha.

Muslim Rohingya juga dilarang untuk bergerak dari satu wilayah ke kawasan lainnya di dalam Myanmar. Apalagi untuk pergi ke luar negeri secara legal, seperti halnya melaksanakan haji. Hal inilah yang membuat mereka melarikan diri pergi ke Negara lain yang mereka nilai lebih aman. Cara mereka pergi pun juga tidak memiliki standar keselamat. Terkadang satu perahu kecil diisi oleh puluhan orang termasuk wanita dan anak-anak. Kondisi inilah yang terkadang menyebabkan mereka disebut sebagai manusia perahu (Gill, 2015).

Namun keadaan kondisi mereka di pengungsian juga tidak lebih baik, sebab perlakuan dari para penyelundup manusia maupun dari negara-negara yang tidak mau menerima mereka. Atau jika pun mereka diterima di suatu Negara, tetapi keberadaan mereka sebenarnya illegal. Hal ini dikhawatirkan justru akan menyebabkan terjadinya ekploitasi dan berbagai hal yang tidak diinginkan lainnya.

Sejauh ini, Malaysia merupakan tujuan paling banyak dari para pengungsi Rohingya. Hanya saja sejauh ini asimilisasi mereka terhadap masyarakat lokal belum begitu baik, terutama melalui pernikahan. Meskipun demikian, melalui berbagai NGO dan lembaga sosial lainnya, Malaysia sudah menyediakan berbagai fasilitas seadanya untuk akses pendidikan dan bermain bagi para anak-anak pengungsi. Dengan demikian diharapkan mereka tidak terlalu larut dalam trauma persoalan yang sedang menghimpit (Letchamanana, 2013:86).

Demikian juga dengan Thailand, sejauh ini jumlah pengungsi Rohingya juga cukup besar. Pada tahun 2013, pihak otoritas Thailand mengumumkan bahwa jumlah pengungsi illegal di negeri gajah ini sudah mencapai lebih dari 6000 orang, baik laki-laki, wanita dan anak-anak sejak Oktober 2012. Keadaan mereka pun juga cukup memprihatinkan karena pemerintah Myanmar tidak bisa menerima mereka, bahkan tidak sedikit yang dikembalikan ke lautan lepas (Coates, 2013). 
Belum lagi di Bangladesh, kondisi mereka sebagian besar digambarkan sebagai pengungsi illegal. Bahkan selain kondisi sosial ekonomi yang memperihatinkan, mereka juga tidak mendapatkan akses untuk pendidikan terutama dari kalangan anakanak. Sebelum datang ke Bangladesh pun kebanyakan dari para pengungsi ini belum mempunyai kemampuan yang baik dalam membaca dan menulis. Oleh karena itu, tidak sedikit di antara mereka yang ditangkap dan dideportasi ke Negara asal mereka (Peterson, 2015). Padahal sebagaimana di atas di sampaikan, di Myanmar pun mereka tidak diterima sebagai warga Negara.

Pada akhirnya kasus Rohingya menjadi salah satu tragedy kemanuiaan serius di era ini. Tidak hanya itu, karena banyak isu yang berkaitan dengan identitas masyarakat Rohingya yang muslim dan kelompok pemerintah yang didukung oleh para tokoh Budha, konflik Myanmar pun bergeser menjadi konflik agama. Dengan demikian, konflik Rohingya pun berdampak luas, tidak hanya di Myanmar tetapi juga di Negara-negara tetangga ASEAN lainnya termasuk di Indonesia. Di Malang misalnya, beberapa kali masyarakat muslim terlihat mendatangi tokoh agama Budha dalam upaya untuk menyatakan sikap penentangan terhadap sikap sewenang-wenang yang dilakukan oleh pemerintah dan lembaga terkait terhadap masyarakat muslim di Myanmar.

\section{Perhatian Dunia Internasional}

Meskipun keadaan muslim Rohingya sudah sangat memprihatinkan sejak waktu yang lama, dunia Internasional selama ini terlambat memberikan respon, termasuk dunia Islam. Adapun jika mereka sudah memberikan pernyataan sikap, tetapi belum ada yang melakukan tindakan konkret dan sistematis untuk menyelesaikan akar persoalan. Sejauh ini respon yang mereka berikan baru muncul pada tahun 2012 ketika konflik Rohingya semakin intens diangkat melalui berbagai media massa (Khadijah, 2014).

Saat dunia mulai menyadari berbagai persoalan serius yang menimpa masyarakat Rohingya, maka beberapa di antara mereka bersedia untuk menyediakan tempat penampungan bagi para pengungsi Rohingya, tetapi pelayanan yang diberikan juga belum optimal. Sejauh ini, berdasarkan informasi tahun 2009, sudah ada 500.000 
masyarakat Rohingya yang tinggal di Saudi Arabia, 200.000 di Pakistan, dan 50.000 di Uni Emirat Arab, serta di beberapa negara tetangga lainnya (Sidhu \& Parnini, 2011).

Bangladesh sebagai negara terdekat dengan Rohingya merupakan negara yang mendapatkan banyak pengaruh dari kekerasan muslim Rohingya. Sejak tahun 1978, para pengungsi Rohingya sudah berdatangan ke negeri Bengali ini. Bahkan jumlah mereka sudah lebih dari 200.000 an. Adapun keadaanya adalah tinggal di tenda-tenda pengungsian dan keadaan mereka dalam keadaan yang sulit (Kipgen, 2014: 234-247). Kondisi ini tentu memprihatinkan, sebab Bangladesh sebagai negara miskin akan menghadapi persoalan dalam negeri, utamanya dalam hal ekonomi, disamping itu pemerintah Myanmar dalam bekerjasama ekonomi dengan Bangladesh mensyaratkan agar para pengungsi tersebut dikembalikan.

Adapun di Bangladesh yang mempunyai hubungan erat dengn Rohingya karena darah dan suku, para pengungsi yang datang dari Rohingya mengalami penolakan. Jika pun ada yang sudah masuk ke wilayah mereka, maka pemerintah melarang untuk memberikan bantuan kesehatan, makanan, minuman, dan bantuan lainnya kepada para pengungsi. Bahkan bagi sebagainan yang belum masuk, maka pemerintah Bangladesh membiarkan mereka untuk kembali ke lautan yang sangat mungkin menyebabkan para pengungsi ini mengalami masalah politik dan psikologis. Hal ini bisa dipahami karena pemerintah Bangladesh masih sibuk dengan urusan ekonomi mengingat Negara ini termasuk dalam kategori miskin. Akhirnya, melalui UNICEF, mereka pun memutuskan bahwa berbagai bantuan untuk kesehatan, training dan pendidikan bagi para pengungsi dihentikan (Kiragu et al, 2011).

Adapun pada level organisasi Internasional, Organisasi Konferensi Islam (OKI) sudah menyikapi isu ini dengan mengeluarkan resolusi yang mengkritik junta militer Myanmar pada Juni 2000. Bahkan setiap tahun OKI sudah mengeluarkan statemen tentang isu Myanmar ini. Professor Ekmeleddin Ihsanoglu, selaku SecretaryGeneral of the Organization of Islamic Cooperation misalnya menyatakan bahwa perlu ada upaya bagi pemerintah Myanmar untuk memperhatikan nasib masyarakat minoritas 
muslim di Myanmar. Namun lagi-lagi, belum ada tindakan nyata dan terorganisir untuk menangani persoalan (Zarni, 2013).

Langkah yang cukup konkret justru dilakukan pada level negara anggota OKI. Saudi dan Turki termasuk negara yang akhir-akhir ini sangat getol memperjuangkan muslim Rohingya meskipun secara geografis jarak negara mereka cukup jauh dari Myanmar. Turki bahkan menyatakan siap untuk menampung berapa pun pengungsi Myanmar. Bahkan presidennya pun dalam beberapa waktu yang lalu juga sempat langsung turun melakukan peninjauan keadaan di Myanmar. Sebagaimana halnya Saudi, negara ini pun sudah mengirimkan kapal-kapal besar untuk menyelamatkan para pengungsi yang masih terapung di Samudra India.

Adapun Amerika, sejak tahun 1991, mereka sudah memberikan bantuan kemanusiaan terhadap para pengungsi Myanmar di Bangladesh melalui Palang Merah Internasional meski kurang menyentuh akar persoalan. Amerika melarang Bangladesh untuk mengembalikan para pengungsi ke Myanmar, di samping juga memberikan fasilitas pendidikan untuk anak-anak para pengungsi. Berbagai kegiatan yang dilakukan oleh Amerika tadi difasilitasi oleh Christian Solidarity Worldwide (Lembaga Solidaritas Kristen Dunia). Bahkan Amerika juga mendesak pemerintah Myanmar untuk memberikan hak kewarganegaraan penuh kepada masyarakat Rohingya agar mereka bisa mendapatkan akses pelayanan yang merata sebagaimana warga Negara lainnya (Sidhu \& Parnini, 2011).

Demikian juga dengan PBB, hak veto telah membuat dunia Internasional seakan hanya dikuasai oleh beberapa Negara besar saja. Jika kasus Rohingya di bawah ke forum PBB misalnya, maka meskipun 99 \% Negara setuju untuk memberikan sanksi kepada pemerintah Myanmar, tetapi ada satu Negara pemilik hak veto yang menolak, maka suara mayoritas tadi tidak akan berpengaruh apa-apa.

Lebih-lebih kebanyakan Negara berkembang termasuk Indonesia memberikan sumbangan sangat kecil dalam pendanaan PBB dibandingkan dengan Negara-negara maju tadi, seperti Amerika. Pada akhirnya, banyak kebijakan Internasional hanya diselesaikan di atas meja makan. Ada pun forum-forum Internasional hanya 
menjadi formalitas saja. Oleh karena itu, penyelesaian masalah Rohingya dengan mengandalkan sistem Internasional melalui PBB masih sulit dari harapan.

Berkaitan dengan isu Rohingya, sejauh ini PBB baru bisa merekomendasikan agar UNHCR dilibatkan dalam mencari fakta yang sebenarnya terjadi di lapangan. Selain itu, PBB juga menyerukan supaya Myanmar pada level Negara segera menyelesaikan persoalan secara damai. Dalam hal ini, berbagai elemen aktor Internasional diminta untuk terlibat bertanggungjawab dalam mencegah berbagai tragedy kemanusiaan di Myanmar (Robinson \& Rahman, 2012:16-20).

Maka dari penjelasan di atas terlihat bahwa apa yang dilakukan dunia selama ini baru merupakan respon dari isu dan bukan kebijakan strategis untuk menyelesaikan persoalan dari akarnya. Meskipun dalam isu kemanusiaan selama ini dunia Internasional begitu getol bersuara, tetapi hal tersebut tidak terjadi ketika berhadapan dengan isu Rohingya.

Melihat respon dunia Internasional yang belum serius tersebut, maka pemerintah Myanmar pun menanggapnya sebagai angin lalu. Mereka selalu beralasan bahwa muslim Rohingya akan diterima di Myanmar hanya jika mereka mau mengakui diri sebagai masyarakat yang berasal dari Bengali (Bangladesh). Padahal realitanya, apa yang diminta pemerintah Myanmar tersebut hanya alasan saja. Buktinya berbagai kebijakan yang dilakukan terhadap masyarakat muslim, termasuk Rohingya terlihat sebagai upaya sistematis untuk menghilangkan entis Rohingya dari Myanmar.

\section{ASEAN dan Penyelesaian Masalah Rohingya}

Sejauh ini ASEAN dikenal sebagai organisasi regional tersukses di dunia setelah European Union. Dalam penyelesaian berbagai konflik dan penyelesaian pelanggaran HAM, ASEAN juga dikenal telah melakukan upaya aktif di berbagai Negara anggota (Zyck, Fan, and Price, 2014:1-6). Oleh karena itu, disamping ada beberapa Negara yang mendapatkan pengaruh karena jumlah pengungsi Rohingya yang kian bertambah, beberapa Negara mulai menekan ASEAN untuk memberikan perhatian lebih dan mengangkat isu Rohingya sebagai persoalan regional. 
Namun demikian dalam persoalan Rohingya yang merupakan salah satu peristiwa pelanggaran HAM terbesar yang hanya diberitakan beberapa tahun ini, ASEAN seakan tidak bisa melakukan upaya efektif dengan eksitensinya sebagai kerjasama regional di Asia Tenggara. Myanmar pun menolak jika persoalan Rohingya dibawa pada level high level dialogue. Menurut Myanmar berdasarkan ASEAN Charter disebutkan bahwa ASEAN tidak punya hak untuk melakukan intervensi terhadap persoalan domistik suatu Negara (Baskoro, 2016).

Meskipun demikian seharusnya sebagai organisasi regional, ASEAN tidak hanya terpaku pada perkara yang bersifat procedural. Apa yang terjadi di tengah masyarakat Rohingya bukan sekedar persoalan politik domistik semata, melainkan sudah menjadi isu kemanusia. Hal ini bisa terlihat dari upaya yang begitu sistematis dari pemerintahan junta militer untuk menghabisi masyarakat muslim Rohingya. Bahkan beberapa tokoh Budha menyampaikan secara terbuka bahwa bangsa Rohingya tidak punya hak untuk tinggal di Myanmar dan harus pergi ke daerah yang lain. Yang terjadi adalah beberapa Negara terkait secara sukarela melakukan upaya kemanusiaan untuk menangani masalah pengungsian dengan menyediakan tempat penampungan sementara bagi mereka. Padahal menyikapi persoalan Rohingya ini, sekjen PBB Ban Ki Moon telah menyampaikan bahwa ASEAN punya kewajiban untuk menyelesaikan persoalan ini (Kim \& SIM Global Education, 2015).

Thailand dan Malaysia juga merupakan dua negara lainnya yang berbatasan dan terpengaruh secara signifikan dengan kekerasan terhadap muslim Rohingya. Meskipun demikian para pengungsi Rohingya tidak mendapatkan perlindungan hukum di kedua Negara ini. Ketika masuk atau keluar dan berpindah dari satu tempat ke tempat lain mereka senantiasa dalam pengawasan dan pemeriksaan. Lebih dari 150.000 pengungsi dari Myanmar berada di Thailand. Sama seperti Bangladesh, pemerintah Thailand berusaha untuk mendeportasi penduduk muslim Rohingya tersebut ke negara asalnya. Bahkan beberapa sikap kurang berkemanusiaan pun dilakukan oleh pemerintah Thailand dengan melepas mesin perahu-perahu para pengungsi kemudia memaksa 
mereka untuk kembali ke lautan lepas. Sejak 2008 sampai 2009 saja, tidak kurang dari 1200 orang yang sudah dideportasi melalui perahu (Lewa, 2009:11).

Adapun di Malaysia, masyarakat Rohingya sebenarnya sudah mulai meminta suaka kepada pemerintah Malaysia sejak tahun 1980. Hanya saja ketika mereka sudah sampai di Malaysia, hanya sedikit di antara mereka yang terdaftar secara legal, adapun sisanya merupakan para pengungsi illegal. Dikarenakan Malaysia merupakan Negara yang tidak mengakui prinsip jus solis, anak-anak yang lahir di daerah pengungsian ini tidak menjadi penduduk Malaysia dan mengalami nasib tanpa kewarganegaraan sebagaimana orang tua mereka. Oleh karena itu, beberapa pakar telah merekomendasikan pemerintah Malaysia untuk menyikapi kondisi ini secara arif (Weissbrodt \& Collins, 2006:245-276).

Para pengungsi ini berbeda dengan para pengungsi lainnya yang masih memungkinkan untuk dikembalikan ke Negara asal mereka. Sementara penduduk Rohingya merupakan masyarakat tanpa Negara yang jika dikembalikan tanpa ada system Internasional yang mengatur justru akan menyebabkan mereka kembali mendapatkan perlakuan keras dan diskriminatif dari pemerintah Myanmar.

Namun demikian, hal yang perlu diapresiasi dari pemerintah Malaysia adalah sikap dari mantan Perdana Menteri Malaysia, Ahmad Badawi, yang menyatakan bahwa kasus Rohingya tidak hanya sekedar masalah domistik Myanmar melainkan sudah merupakan persoalan yang harus diselesaikan paling tidak secara regional. Hal ini dikarenakan pengaruh dari kekerasan Rohingya di Myanmar sudah mempengaruhi negara-negara tetangga. Menurut beliau, apa yang terjadi di Myanmar juga akan mempengaruhi image dan kredibilitas ASEAN. Oleh karena itu, ia menuntut pemerintah Myanmar untuk segera mengambil langkah strategis untuk menyelesaikan masalah domistik berkaitan dengan isu Rohingya (Sidhu, 2008).

Namun rupanya seruan Malaysia ini tidak mendapatkan perhatian cukup dari para pemimpin ASEAN. Upaya diplomatik terhadap pemerintah Myanmar tidak optimal dilakukan. Penanganan terhadap para pengungsi Rohingya yang terapung selama berbulan-bulan di samudra Hindia juga tidak mendapatkan perhatian serius. Sejauh ini, 
apa yang dilakukan ASEAN untuk muslim Rohingya baru sekedar pandangan, dan belum mempunyai agenda yang konkret untuk menangani persoalan.

Hal ini misalnya ditunjukkan oleh Surin Pitsuwan, Sekretaris General ASEAN, yang mengingatkan Myanmar agar tidak melakukan kekerasan sekterian. Jika konflik ini terus berlangsung maka pengaruhnya bahkan bisa meluas ke beberapa Negara tetangga lain yang akan mempengaruhi juga stabilitas politik dan keamanan kawasan ASEAN. Secara otomatis persoalan ini juga akan memberikan efek terhadap kehidupan ekonomi di kawasan (Kipgen, 2014: 234-247).

Di antara kesulitan ASEAN untuk berperan aktif dalam penyelesaian masalah Rohingya adalah karena prinsip tidak boleh intervensi terhadap kasus-kasus yang terjadi pada Negara anggota. Selain itu, juga komitmen untuk menyelesaikan masalah Rohingya belum terlihat jelas di kalangan para pemimpin ASEAN. Boleh jadi hal ini dikarenakan minimnya informasi berimbang tentang realita sebenarnya yang mereka dapatkan (Goh, 2000:439). Para pemimpin ASEAN pun kebanyakan masih terjebak dengan hal-hal yang bersifat normative dalam sistem Internasional. Hal ini pada akhirnya tidak memungkinkan mereka untuk menyelesaikan masalah ASEAN atas nama kemanusiaan. Akibatnya, sejauh ini banyak persoalan kemanusiaan yang terjadi di kawasan ASEAN yang belum mendapatkan penanganan secara optimal.

Sebenarnya ada beberapa hal lain yang bisa dilakukan oleh ASEAN dalam memberikan peran lebih aktif dalam penyelesaian masalah Rohingya. Apalagi sejak tahun 2009 ASEAN sudah punya lembaga ASE AN Intergovernmental Commission on Human Rights (AICHR). Pada tahun 2011, ASEAN juga membentuk the ASEAN Humanitarian Assistance (AHA) Centre for disaster management. Dengan dua lembaga ini, secara struktural seharusnya ASEAN bisa berperan aktif dalam menyelesaikan masalah Rohingya. Hanya saja karena mandat yang dimiliki oleh dua lembaga ini terbatas dan tidak bisa melakukan intervensi terhadap kedaulatan Negara lain, maka peran yang bisa dilakukan pun tidak optimal. Selain itu, secara power kedua lembaga ini tidak terlalu punya pengaruh signifikan. Keputusan yang mereka ambil tidak sepenuhnya mengikat melainkan lebih pada posisi rekomendasi semata. Meskipun sudah dibentuk 1993, lembaga ini pun 
akhirnya menjelma seperti halnya macan ompong (Kaewjullakarn \& Kovudhikulrungsri, 2015).

Memang ada pendapat yang menyatakan bahwa kekurangan dari AICHR adalah karena upaya penyelesaian isu HAM hanya pada aspek normative dan tidak sampai membawa kasus pelanggaran HAM ke pengadilan. Oleh karena itu, sebagian menyarankan bahwa ASEAN dalam mengefektifkan kinerja AICHR seharusnya juga mempunyai lembaga pengadilan HAM pada level regional (Arendshorst, 2009). Dengan adanya lembaga pengadilan maka akan memudahkan proses pemberian sanksi terhadap Negara yang melakukan pelanggaran HAM, Myanmar dalam hal ini. Selama tidak ada sanksi yang diberikan maka penyelesaikan masalah HAM akan sulit diselesaikan.

Namun demikian, dalam implementasinya dalam berbagai forum ASEAN seakan ada upaya untuk mencegah diskusi tentang kekerasaan. Atas nama non interverence, ASEAN juga tidak bisa memberikan tekanan kepada pemerintah Myanmar untuk menangani masalah yang tidak menciderai nilai-nilai kemanusiaan. Padahal menurut beberapa pakar, implementasi prinsi non intervensi tidak boleh bermakna lepas tangan terhadap Tragedi kemanusiaan yang berlangsung. Hal ini telah diatur oleh PBB untuk mencegah terjadinya genocide dengan mengeluarkan aturan The Responsibility to Protect (Othman, n.d.).

\section{Kesimpulan}

Berdasarkan penjelasan di atas, terlihat jelas bahwa persoalan Rohingnya merupakan isu serius dan merupakan salah satu tragedi kemanusiaan di era ini. Para penduduk muslim Rohingya tidak diakui sebagai warga Negara di Myanmar, demikian juga di luar negeri, mereka menjadi masyarakat yang kehilangan identitas kewarganegaraannya. Padahal mereka tinggal di daerah Rakhine sudah sejak ribuan tahun yang lalu. Berkaitan dengan hal tersebut, berbagai Negara baik secara individu maupun organisasi regional dan internasional sudah melakukan berbagai upaya intervensi yang terangkum dalam semangat Responsibility to Protect. Mereka mengklaim bahwa tragedi kemanusiaan Rohingya harus segera diselesaikan karena melukai nilai-nilai moralitas dan 
kemanusiaan. Semangat ini pun sudah menjadi gerakan legal formal yang didukung oleh berbagai element Internasional.

Hanya saja, langkah konkrit untuk menyelesaikan masalah baik pada level bilateral, regional, maupun Internasional belum begitu terlihat. Berbagai upaya yang dilakukan masih lebih banyak bersifat normative, bahkan untuk kepentingan politik rejim tertentu. Hal ini di antaranya disebabkan karena prinsip non intervensi dan kurangnya power dalam menangani persoalan serta berbagai kepentingan tersembunyi. Oleh karena itu, Responsibility to Protect utamanya dalam penyelesaian masalah Rohingya hanya bisa dilakukan jika semua pihak mempunyai komitmen yang kuat untuk berpihak kepada nilai-nilai moralitas dan kemanusiaan dengan melakukan langkah konkret dalam menyelesaikan akar persoalan.

\section{Daftar Rujukan}

Arendshorst, John. (2009). Dilemma of Non-Interference: Myanmar, Human Rights, and the ASEAN Charter, The. Nw. UJ Int'l Hum. Rts. 8: 102.

Baskoro, Riski Muhamad. (2017). Examining ASEAN Charter of Human Rights: Study Case of Robingya Crisis. Accessed January 8,. http://journalsweb.org/siteadmin/upload/7676ED716005.pdf.

Chandler, David. (2010). R2P or Not R2P? More Statebuilding, Less Responsibility. Global Responsibility to Protect 2, no. 1: 161-166.

Coates, Eliane. (2013). Rohingya Boat People: A Challenge for Southeast Asia. https://dr.ntu.edu.sg/handle/10220/13330.

Dryden-Peterson, Sarah. (2015). The Educational Experiences of Refugee Children in Countries of First Asylum. Washington, DC: Migration Policy Institute. http://www.migrationpolicy.org/sites/default/files/publications/FCD_Dry en-Peterson-FINALWEB.pdf

Ekeh, Chizom, and Martin Smith. (2007). Minorities in Burma. Minority Rights Group International 30. http://www.refworld.org/pdfid/47298f632.pdf. 
Frontières-Holland, Médecins Sans. (2002). 10 Years for the Rohingya Refugees in Bangladesh: Past, Present and Future. MSF-Holland, March 5. http://www.rnapress.com/data/itemfiles/5ae98e43d068cb749b3060b002601b95.pdf.

Gill, Fiona Shaista. (2015). Human Rights and Statelessness: The Case Study of the Robingya in Myanmar. LAP LAMBERT Academic Publishing.

Goh, Gillian. (2000). The 'ASEAN Way: Pacific Review 13, no. 3: 439.

Kaewjullakarn, Saovanee, and Lalin Kovudhikulrungsri. (2015). What Legal Measures Should Asean Apply To Help The Robingya? Accessed January 8, 2017. http://klibel.com/wpcontent/uploads/2015/04/KLIBEL6_Law_11_2ffmN03Wuj.pdf.

Kim, Felix Tan Thiam, and SIM Global Education. ASEAN Politics: Playing Pass-Who Should Accept Responsibility for the Rohingya Refugees at Sea? Accessed January $8, \quad 2017$. http://www.pbic.tu.ac.th/main/sites/default/files/ICAS\%20Paper\%20A14 4\%20-Felix \%20Proofread.pdf.

Kipgen, Nehginpao. (2014). Addressing the Rohingya Problem: Journal of Asian and African Studies 49, no. 2: 234-247.

Kiragu, Esther, Angela Li Rosi, and Tim Morris. (2011). States of Denial: A Review of UNHCR's Response to the Protracted Situation of Stateless Rohingya Refugees in Bangladesh. Policy Development and Evaluation Service, UNHCR. Retrieved from: Http://wnw. Unhor. Org/4ee754c19. Pdf. http://www.netipr.org/policy/downloads/20111201_UNHCR-states-ofdenial.pdf.

Letchamanana, Hema. (2013). Myanmar's Rohingya Refugees in Malaysia: Education and the Way Forward. Journal of International and Comparative Education 2, no. 2: 86.

Lewa, Chris. (2009). North Arakan: An Open Prison for the Rohingya in Burma. Forced Migration Review, no. 32: 11. 
Nemoto, Kei. (2013). The Robingya Issue: A Thormy Obstacle between Burma (Myanmar) and Bangladesh,. http://burmalibrary.org/docs14/Kei_Nemoto-Rohingya.pdf.

Othman, Muhammad Fuad, Zaheruddin Othman, Kamarul Faizal Hashim, and Alias Azhar. Between Non-Interference and Resposibility To Protect: The Plight of the Rohingya People. Accessed January 8, 2017. https://www.researchgate.net/profile/Muhammad_Othman6/publication/ 304223271_Between_Noninterference_and_Resposibility_To_Protect_The_Plight_of_the_Rohingya_ People/links/5769fc7e08ae7d2478cd8bfb.pdf.

Rahman, KM Atikur. (2015). Ethno-Political Conflict: The Rohingya Vulnerability in Myanmar. International Journal of Humanities and Social Science Studies 2, no. 1: 288-295.

Rahman, Siti Khalijah Binti Haji Abdul. Rohingya Muslim Ethnic Violence: World's Response and The Role of United Nations. Accessed June 13, 2017. http://ukmsyariah.org/terbitan/wp-content/uploads/2015/10/09-SitiKhalijah-Abd-Rahman.pdf.

Robinson, Ian G., and Iffat S. Rahman. (2012). The Unknown Fate of the Stateless Rohingya. Oxford Monitor of Forced Migration 2, no. 2: 16-20.

Sarkin, Jeremy, and Marek Pietschmann. (2003). Legitimate Humanitarian Intervention under International Law in the Context of the Current Human Rights and Humanitarian Crisis in Burma (Myanmar). Hong Kong LJ 33: 371.

Sidhu, Jatswan S. Malaysia-Myanmar Relations Since 1958. Accessed June 13, 2017. http://jis.uum.edu.my/images/pdf/4jis/5malaysiaa.pdf.

Sidhu, Jatswan S., and Syeeda Naushin Parnini. International Responses to Human Rights Violations in Myanmar: The Case of the Rohingya. Accessed June 13, 2017.

https://www.researchgate.net/profile/Jatswan_Singh/publication/3129427

76_International_Responses_to_Human_Rights_Violations_in_Myanmar_T he_Case_of_the_Rohingya/links/588aae4092851cc55d3d0948/Internationa 
1-Responses-to-Human-Rights-Violations-in-Myanmar-The-Case-of-theRohingya.pdf.

Steinberg, David I. (2010). Aung San Suu Kyi and US Policy toward Burma/Myanmar. Journal of Current Southeast Asian Affairs 29, no. 3: 35-59.

Weissbrodt, David S., and Clay Collins. (2006). The Human Rights of Stateless Persons. Human Rights Quarterly 28, no. 1: 245-276.

Zarni, Maung. (2013). Buddhist Nationalism in Burma. Tricycle, Spring,. http://www.academia.edu/download/30900393/burmese_Buddhist_racism _final_print_version_from_Tricycle_Spring_2013_T.pdf.

Zongze, Ruan. (2012). Responsible Protection: Building a Safer World. China International Studies 34: 2012-06.

Zyck, S., Lilianne Fan, and Clare Price. ASEAN and Humanitarian Action: Progress and Potential. ASEAN and Humanitarian Action-Jakarta Expert Roundtable, Jakarta, 2014， 1-6. http://etd.lib.nsysu.edu.tw/ETD-db/ETDsearch/view_etd?URN=etd-0715114-125135. 